\title{
POPULATION FLUCTUATIONS AND CHEMICAL CONTROL OF THRIPS TABACI LINDEMAN AND Delia antiqua MEIGEN, ON GARLIC IN FAYOUM GOVERNORATE
}

\author{
SABRA, I. M. and H.M. ABDEL - WARETH
}

Plant Protection Research Institute- ARC, Dokki

(Manuscript received 12 February 2012)

\begin{abstract}
Garlic in Egypt is usually attacked in the field by $T$. tabaci Lindeman and $D$. antiqua Meigen. This work aims to investigate the population fluctuations of both insects on garlic crop under Fayoum governorate conditions as well as their chemical control using chlorpyriphos and fenitrothion insecticides. Data obtained revealed that the population of $T$. tabaci ranged $4-605$ insects/10 plants, while that of $D$. antiqua ranged $1.3-6.0$ larvae/100 plant. The highest infestation percentage with $D$. antiqua was 9.3 and $11.4 \%$ in 2008/2009 and 2009/2010 seasons. Chemical treatment for both insect pests with chlorpyriphos and fenitrothion gave a good control over $90 \%$ in the two seasons.
\end{abstract}

\section{INTRODUCTION}

Onion thrips, Thrips tabaci Lindeman, (Thysanoptera: Thripidae) is a major pest of garlic plants which causes severe foliage damage in the warm weather. Nymphs and adults rasp the leaves and other plant tissues to encourage the release of sap, which is then consumed. When damage is severe, the entire plant may wilt and die. Thrips are hard to control through biological controls because of their mobility and numbers. They migrate in large numbers (in billions) from neighboring areas that are drying up.

In recent years, onion maggot, Delia antiqua Meig. (Diptera: Anthomyiidae) [Hylemia antiqua] has become an important insect pest on garlic, which can cause heavy damage to young plants causing rapid secondary infection by fungi and bacteria (Gouinguene et al., 2005). There are several generations per year of $D$. antiqua which cause yield losses ranged 20-30\% (Gwen Ritcey, 1998, Marius and Frasin, 2008 and Becherescu, 2009).

The present work is the first study aims to throw the light on the population fluctuations of $T$. tabaci and $D$. antiqua on garlic crop and their chemical control in Fayoum, Egypt. 


\section{MATERIALS AND METHODS}

To study the population density and chemical control of insect pests of garlic, $T$. tabaci and D. antiqua, cloves of garlic (Balady variety) were planted in mid October, 2008/9 and 2009/10 at Fayoum. The experimental area was 1/4 feddan, divided into two equal sections. The first was divided into three equal replicates, each contained 70 rows $x 4 \mathrm{~m}$ long. The second was divided into four equal replicates $\times 3$ treatments and three rows were left between replicates as guard rows to prevent the drift of used compounds. Each replicate contained 14 rows $\times 4 \mathrm{~m}$ and $50 \mathrm{~cm}$ wide and the distance between cloves was $10 \mathrm{~cm}$, the cloves were planted on both sides of the rows. The experimental area received all normal agriculture practices and no insecticides were used in the first section.

\section{A- Onion thrips T. tabaci \\ a- Population studies}

To evaluate the population density of this insect, two weeks after planting, three random samples of 10 plants were biweekly taken from each replicate of the first section. The samples were examined using a hand lens to record numbers of nymphs and adults per plant.

\section{b- Chemical control studies}

Two insecticides, chlorpyriphos 48\% EC and fenitrothion $50 \%$ EC were applied in March for one time to control T. tabaci at the rate of $500 \mathrm{~cm}^{3} / 100 \mathrm{~L}$ in the second section. Directly before spraying, four samples, 10 plants each, were randomly taken from each treatment in addition to the control. Similar samples were also taken 1, 3 and 7 days after spraying. The samples were directly transferred to the lab. and examined with a hand lens to record the total numbers of thrips (nymphs and adults).

\section{B- Onion maggot $D$. antiqua}

\section{a- Population studies}

Also, two weeks after planting a random sample of 100 plants was collected biweekly from the specified area and transferred directly to the laboratory. The plants were dissected to record either number of dead hearts or larvae. The specimens of larvae were preserved in preservative solution (95\% ethyl alcohol $90 \%+5 \%$ glycerol) and identified by Natural History Museum (Switzerland)

b- Chemical control studies:

The experiment was conducted to determine the efficacy of the same pesticides with the same rates used against thrips to elucidate its efficiency against $D$. antiqua. Six weeks after plantation, spraying procedures were carried out for one time when the numbers of maggots reached a higher levels in the beginning of December. Four 
samples of 100 plants from each treatment in addition to the control were also collected before and after spraying as before. The samples were transferred to the lab. and dissected to record the number of larvae. Reduction percentages were calculated according Henderson and Telton formula (1955).

\section{RESULTS AND DISCUSSION}

\section{A- Onion thrips T. tabaci \\ a- Population fluctuation}

As shown in table (1) the population of this pest began early in the season on the seedlings stage, two weeks after plantation with relatively low numbers and gradually increased to reach its maximum at the end of the season. The population density was generally higher in 2008/09 than 2009/10 season. The population tended to rise up gradually till the beginning of January where it exhibited higher levels and showed a flat peak on Jan., 20 \& Feb., 3 for 2008/2009 season. On the second season, however, the population sharp rise was noticed on Jan., 5 and continued at higher attitudes till the end of the season.

The lowest population densities of T. tabaci were 5.0 and 4.0 insects/10 plants at seedlings at the end of October in 2008/09 and 2009/10 season, respectively. The highest population densities were 605 and 516 insects/10 plants during the end of March in 2008/09 and 2009/10 season, respectively. In this respect, Lorini and Junior (1990), in Brazil, reported that, T. tabaci population on garlic stayed low from planting until mid-September (less than 10 thrips/plant) even though food was abundant and the mean number of thrips/plant reached 174.6 in mid-November. Also, Boas et al. (1995) found that, the maximum population numbers of this insect ranged 26.7 - 37.2 /garlic plant. In Pakistan, Hussain, et al., (1997) found that, the infestation began at the beginning of December and continued to the end of April varying from 0.02 to 2.50 thrips/plant. The peak of infestation was recorded from the end of March to the end of April. 
Table 1. Biweekly counts of T. tabacil10 garlic plants, during 2008/2009 and 2009/2010 seasons.

\begin{tabular}{|c|c|c|c|}
\hline \multicolumn{2}{|c|}{$2008 / 2009$} & \multicolumn{2}{c|}{ 2009/2010 } \\
\hline Date & Counts & Date & Counts \\
\hline 2008 Oct. 28 & 5 & 2009 Oct. 27 & 4 \\
\hline Nov. 11 & 9 & Nov. 10 & 28 \\
\hline Nov. 25 & 27 & Nov. 24 & 31 \\
\hline Dec. 9 & 28 & Dec. 8 & 70 \\
\hline Dec. 23 & 53 & Dec. 22 & 192 \\
\hline 2009 Jan. 6 & 116 & 2010 Jan. 5 & 415 \\
\hline Jan. 20 & 363 & Jan. 19 & 443 \\
\hline Feb. 3 & 510 & Feb. 2 & 451 \\
\hline Feb. 17 & 509 & Feb. 16 & 356 \\
\hline Mar. 3 & 494 & Mar. 2 & 451 \\
\hline Mar. 17 & 453 & Mar. 16 & 516 \\
\hline Mar. 31 & 605 & Mar. 30 & \\
\hline
\end{tabular}

The present study revealed however, that $T$. tabaci was widespread in Fayoum all season round from planting until harvest in relatively high numbers and must be controlled according to Boas et al., (1995) who recommended that insecticides should be sprayed over garlic fields when 20 thrips (larvae and adults) are sampled per plant.

\section{B- Chemical control}

Data presented in table (2) revealed that, fenitrothion $50 \%$ and chlorpyriphos $48 \%$ at the rate of $500 \mathrm{~cm}^{3} / 100$ L. were effective against $T$. tabaci in the garlic field. The initial reductions caused by the two insecticides were 88.5 and $86.5 \%$ in the first season and 90.1 and $84.6 \%$ in the second one, respectively. Regardless of season, the highest reduction was obtained three days after treatment, $93.4-97.7 \%$.

Table 2. Reduction percentages of T. tabaci after chemical treatments during 2008/09 and $2009 / 10$ seasons.

\begin{tabular}{|c|c|c|c|c|c|c|c|}
\hline \multirow{3}{*}{ Treatment } & \multicolumn{4}{|c|}{ Insects/plant } & \multicolumn{3}{|c|}{$\%$ Reduction } \\
\hline & \multirow{2}{*}{$\begin{array}{c}\text { Before } \\
\text { treatment }\end{array}$} & \multicolumn{3}{|c|}{ After treatment } & \multirow{2}{*}{$24 \mathrm{~h}}$. & \multirow{2}{*}{3 days } & \multirow{2}{*}{7 days } \\
\hline & & $24 \mathrm{~h}$. & 3 days & 7days & & & \\
\hline \multirow[b]{2}{*}{ Fenitrothion } & \multicolumn{7}{|c|}{$2008 / 9$} \\
\hline & 98.5 & 11.75 & 2.25 & 7.25 & 88.5 & 97.7 & 93.0 \\
\hline Chlorpyriphos & 74.5 & 10.5 & 2.75 & 5.75 & 86.5 & 96.4 & 92.7 \\
\hline Control & 93.75 & 97.5 & 95.25 & 98.75 & - & - & - \\
\hline \multirow[b]{2}{*}{ Fenitrothion } & \multicolumn{7}{|c|}{$2009 / 10$} \\
\hline & 94.75 & 8.75 & 5.75 & 8.5 & 90.1 & 93.9 & 90.8 \\
\hline Chlorpyriphos & 83.0 & 12.0 & 5.0 & 7.0 & 84.6 & 93.4 & 91.4 \\
\hline Control & 98.75 & 92.5 & 90.25 & 96.5 & - & - & - \\
\hline
\end{tabular}


These findings occupied a middle rank 7, days after treatment, 93.0 - 90.8\%. In India, Rajavel and Suresh (2007) found that, garlic fields sprayed with chlorpyriphos recorded the lowest population of $T$. tabaci, 7 days after treatment.

\section{B- Onion maggot $D$. antiqua}

\section{a- Population fluctuation}

As shown in Table (3), the population density of $D$. antiqua on the garlic plants followed almost a similar trend in 2008/09 and 2009/10 seasons. The infestation started low 4 weeks after plantation, increased gradually and fluctuated throughout the season.

The highest population densities were 5.7 and 6.0 larvae/100 plant in early December in 2008/9 and 2009/10 season, respectively.

Considering the number of $D$. antiqua larvae per plant, two moderate population peaks were evident, the first was in December while the second was in mid February in the two seasons. The total infestation percentage (larvae and dead hearts) were 9.3 and $11.4 \%$ in the first and second season, respectively. In this respect, Haydar and Sherif (1990) found that a small population of $D$. alliaria was present throughout the growing season on onion in Egypt. In Ontario, Gwen Ritcey

Table 3. Biweekly counts of $D$. antiqua larvae and dead hearts/100plants during 2008/2009 and 2009/2010 seasons.

\begin{tabular}{|c|c|c|c|c|c|c|c|}
\hline \multicolumn{4}{|c|}{$2008 / 2009$} & \multicolumn{4}{|c|}{$2009 / 2010$} \\
\hline $\begin{array}{l}\text { Inspection } \\
\text { date }\end{array}$ & $\begin{array}{c}\text { Larvae/100 } \\
\text { plant }\end{array}$ & $\begin{array}{l}\text { Dead hearts } \\
\text { /100 plant }\end{array}$ & $\begin{array}{c}\% \\
\text { Infestation }\end{array}$ & $\begin{array}{l}\text { Inspection } \\
\text { date }\end{array}$ & $\begin{array}{c}\text { Larvae/100 } \\
\text { plant }\end{array}$ & $\begin{array}{c}\text { Dead } \\
\text { heart/100 } \\
\text { plant }\end{array}$ & $\begin{array}{c}\% \\
\text { Infestation }\end{array}$ \\
\hline $\begin{array}{ll}2008 & \text { Oct. } \\
28 & \\
\end{array}$ & - & - & 0.0 & $\begin{array}{ll}2008 & \text { Oct. } \\
27 & \\
\end{array}$ & 0.0 & 0.0 & 0.0 \\
\hline Nov. 11 & 1.7 & - & 1.7 & Nov. 10 & 2.7 & 0.0 & 2.7 \\
\hline Nov. 25 & 4.7 & 0.7 & 5.4 & Nov. 24 & 4.7 & 1.3 & 6.0 \\
\hline Dec. 9 & 5.7 & 2.3 & 8.0 & Dec. 8 & 6.0 & 2.7 & 8.7 \\
\hline Dec. 23 & 3.3 & 4.3 & 7.6 & Dec. 22 & 3.0 & 4.7 & 7.7 \\
\hline 2009 Jan. 6 & 1.7 & 4.0 & 5.7 & 2009 Jan. 5 & 2.0 & 6.0 & 8.0 \\
\hline Jan. 20 & 3.3 & 1.3 & 4.6 & Jan. 19 & 3.7 & 1.0 & 4.7 \\
\hline Feb. 3 & 1.3 & 1.0 & 2.3 & Feb. 2 & 4.3 & 0.3 & 4.6 \\
\hline Feb. 17 & 5.0 & 4.3 & 9.3 & Feb. 16 & 5.7 & 4.3 & 10.0 \\
\hline Mar. 3 & 1.0 & 6.7 & 7.7 & Mar. 2 & 4.0 & 7.7 & 11.4 \\
\hline Mar. 17 & 3.0 & 5.0 & 8.0 & Mar. 16 & 4.0 & 5.0 & 9.0 \\
\hline Mar. 31 & 1.3 & 3.0 & 4.3 & Mar. 30 & 1.3 & 2.7 & 4.0 \\
\hline
\end{tabular}


(1998) reported that the population of $D$. antiqua on garlic peaked in different dates (July, October and November) in different years. Also, Szwejda and Wrzodak (2009) in Poland, reported that, $D$. antiqua was the most common dominant species occurring in all regions of onion production. Becherescu (2009) found that, D. antiqua is a frequent pest in most European countries and causes remarkable losses in onion and other Liliaceae crops.

The field observations revealed that, only one $D$. antiqua larva infest the garlic plant and cause dead heart. The highest percentages of dead plants with the infestation of $D$. antiqua on garlic were 6.7 and $7.7 \%$ in the beginning of March in both seasons, respectively.

\section{B- Chemical control}

Data presented in table (4) showed that, chemical treatment of $D$. antiqua on garlic plants with fenitrothion $50 \%$ and chlorpyriphos $48 \%$ at the rate of $500 \mathrm{~cm}^{3} / 100$ L. was effective in reducing the number of

Table 4. Reduction percentages of $D$. antiqua after chemical treatment during 2008/09 and 2009/10 seasons.

\begin{tabular}{|c|c|c|c|c|c|c|c|}
\hline \multirow{3}{*}{ Treatments } & \multicolumn{4}{|c|}{ larvae/100plants } & \multirow{2}{*}{\multicolumn{3}{|c|}{$\%$ Reduction at indicated days }} \\
\hline & \multirow{2}{*}{$\begin{array}{c}\text { Before } \\
\text { treatment }\end{array}$} & \multicolumn{3}{|c|}{ After treatment } & & & \\
\hline & & $24 \mathrm{~h}$. & 3 days & 7days & $24 \mathrm{~h}$. & 3 days & 7 days \\
\hline \multicolumn{8}{|c|}{$2008 / 9$} \\
\hline Fenitrothion & 8.5 & 1.5 & 0.75 & 1.25 & 83.7 & 92.2 & 86.0 \\
\hline Chlorpyriphos & 10.25 & 2.0 & 1.0 & 1.5 & 82.0 & 91.4 & 86.1 \\
\hline Control & 9.25 & 10.0 & 10.5 & 9.75 & - & - & - \\
\hline \multicolumn{8}{|c|}{$2009 / 10$} \\
\hline Fenitrothion & 9.25 & 1.75 & 0.75 & 2.0 & 80.6 & 91.9 & 77.3 \\
\hline Chlorpyriphos & 11.0 & 2.25 & 1.0 & 2.5 & 79.0 & 90.9 & 76.1 \\
\hline Control & 10.5 & 10.25 & 10.5 & 10.0 & - & - & - \\
\hline
\end{tabular}

infested plants in comparison with the control. The initial effect (one day after treatment) for fenitrothion was slightly higher than chlorpyriphos and ranged 79$83.7 \%$ in the two seasons. The highest effect was obtained within three days of treatment and ranged $90.9-92.2 \%$ in the two seasons. The reduction percentage after 7 days of treatment was slightly lower in the two seasons and ranged $76.1-86.0 \%$. The reduction percentages were relatively low because the larvae of this pest are protected inside garlic stem. Mesic et al. (2008) reported that, the reduction percentage of $D$. antiqua population on onion when sprayed with dimethoate ranged $77.8-100 \%$. 


\section{REFERENCES}

1. Becherescu, A. 2009. Efficacy of integrated protection complexes in fighting against the pest, Delia antiqua Meig. J. of Horticulture, Forestry and Biotechnology. 13: 151-154.

2. Boas, G. L. V., M. C. Branco, J. A. M. Sobrinho and F. H. Franca. 1995. Economic threshold of Thrips tabaci control in garlic grown in the Brasilia region. Horticultura Brasileira. 13 (1): 22-27.

3. Gouinguene, S. P., H. R. Buser and E. Stadler. 2005. Host-plant leaf surface compounds influencing oviposition in Delia antiqua. Chemoecology. 15 (4): 243249.

4. Gwen R. 1998. Onion maggot control. University of Guelph, Jim Chaput - Minor Use Coordinator /OMAFRA. http://www.ontario.ca

5. Haydar, M. F. and L. S. Sherif, 1990. Ecological aspects and developing method of onion pest control. Bull. Entomol. Society of Egypt, Economic Series. 16, 119-126.

6. Henderson, C.F. and E.W. Telton. 1955. Test with acaricides against the brown wheat mite. J. Econ. Entomol., 48: 157-161

7. Hussain, T., M. Iqbal Farmanullah and M. Anwar. 1997. Studies on the population dynamics, varietal preference and chemical control of garlic thrips, Thrips tabaci L. Sarhad J. of Agric. 13 (2): 175-180.

8. Lorini, I. and V. M. Junior. 1990. Population fluctuations of Thrips tabaci L. (Thysanoptera: Thripidae) on garlic crop. Anais da Sociedade Entomologica do Brasil. 19 (2): 367-371.

9. Marius, I. and L. B. Frasin. 2008. Observations on the efficacy of some insecticides in Delia antiqua Meig. pest control. Analele Universitatii din Craiova Biologie, Horticultura, Tehnologia Prelucrarii Produselor Agricole, Ingineria Mediului. 13: 405-408.

10. Mesic, A., J. I. Barcic, J. Barcic, M. Zvonar and I. Filipovic. 2008. Diptera pests control in onions. Fragmenta Phytomedica et Herbologica. 30: 1/2, 5-21.

11. Rajavel, D. S. and K. Suresh. 2007. Preliminary studies on the management of garlic thrips, Thrips tabaci L. (Thysanoptera: Thripidae). Insect Environment. 13 (3): 124.

12. Szwejda, J. and R. Wrzodak. 2009. Phytophagous entomofauna occurring on onion plantations in Poland. Vegetable Crops Research Bull. 71: 5-14. 
Thrips tabaci التقلبات العددية والمكافحة الكيماوية لحشرتي تربس البصل وذبابة البصل الصغيرة Delia antiqua على الثوم بمحافظة الفيوم ابراهيم مخيمر صبرة مادة محمد عبدالحميد معه بحوث وقاية النباتات ، مركز البحوث النراعية ، الدقي - جيزة

أجريت تجارب حقلية لدراسة التقلبات العددية والككافحة الكيماوية لحشرتي تربس البصل ودودة البصل الصغيرة على محصول الثوم تحت ظروف محافظة الفيوم خلال موسمي 2009/2008 2010/2009,

وأظهرت النتائج ان الثوم يصاب بكلا الآفتين بعد الإنبات وتنتمر الإصابة حتى تقليع

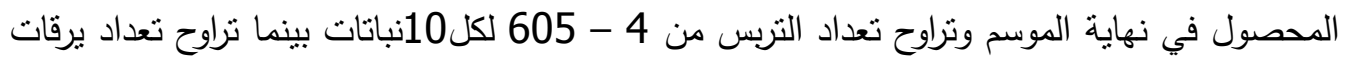

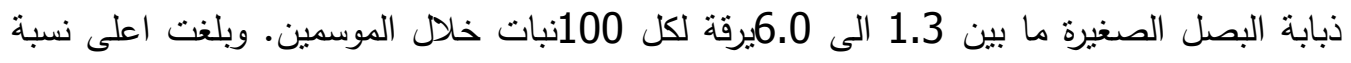

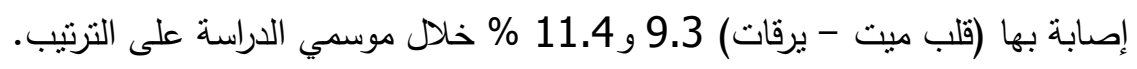

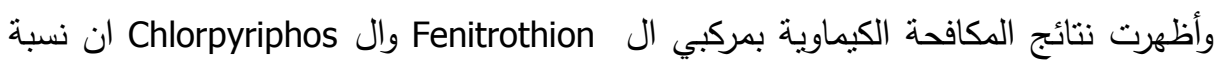

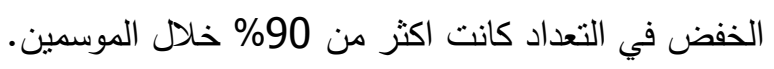

